\title{
Perancangan Media Pembelajaran Interaktif Berbasis Model Pembelajaran Problem Based Learning Mata Kuliah Fisika Dasar
}

\author{
Andrian Syahputra $^{1}$, Suparno $^{2}$, Muhammad Giatman' ${ }^{2}$ Rizki Maulida $^{1}$ \\ ${ }^{1}$ Fakultas Teknik dan Ilmu Komputer, Teknik Informatika, Universitas Potensi Utama, Medan, Indonesia \\ ${ }^{2}$ Fakultas Teknik, Pendidikan Teknologi dan Kejuruan, Universitas Negeri Padang, Padang, Indonesia \\ Email: ${ }^{1}$ andriansyahputra4@gmail.com, ${ }^{2}$ suparno121251@gmail.com, ${ }^{3}$ giat_5131@yahoo.co.id, \\ 4rizkimaulida24@gmail.com
}

\begin{abstract}
Abstrak- Penelitian ini bertujuan untuk merancang sebuah media pembelajaran berbasis dengan model pembelajaran Problem Based Learning (PBL). Penelitian ini termasuk dalam penelitian R\&D (Research and Development) yaitu penelitian yang menghasilkan produk yang dapat digunakan untuk menunjang proses pembelajaran matakuliah fisika dasar di Universitas Potensi Utama. Pembuatan media pembelajaran tersebut menggunakan multimedia flash. Perancangan media pembelajaran ini dibuat oleh praktisi IT yaitu dosen dalam bidang komputer. Selanjutnya untuk menilai kesesuaian materi penelitian ini menggunakan tim ahli dari beberapa dosen fisika dasar dan guru-guru fisika. Hasil dari penelitian ini adalah perancangan Media pembelajaran berbasis PBL ini cukup layak dan sesuai dengan materi fisika khususnya HK. Newton. Penilaian kelayakan materi oleh tim ahli adalah kelayakan isi/kedalaman materi tingkat universitas dengan nilai persentase $82,85 \%$. Kontekstual persentase $81,20 \%$. Kelayakan Penyajian 80,15\%. Kesesuaian dengan model. PBL 86,25\%. Kesesuaian evaluasi dengan tujuan pembelajaran $87,10 \%$.
\end{abstract}

Kata Kunci: Media Pembelajaran Interaktif, Problem Based Learning, Fisika Dasar, R\&D, Model Pembelajaran.

\begin{abstract}
This study aims to design a learning media based on the Problem Based Learning (PBL) learning model. This research is included in R\&D (Research and Development) research, which is research that produces products that can be used to support the learning process of basic physics courses at Potensi Utama University. Making learning media using flash multimedia. The design of instructional media is made by IT practitioners, namely lecturers in the field of computers. Furthermore, to assess the suitability of the material of this study using a team of experts from several basic physics lecturers and physics teachers. The results of this study are the design of PBL-based learning media is quite feasible and in accordance with the physics material, especially HK. Newton. The assessment of the material suitability by the expert team is the feasibility of the content / depth of university level material with a percentage value of $82.85 \%$. Contextual percentage of $81.20 \%$. Presentation Feasibility $80.15 \%$. Conformity to the model. PBL $86.25 \%$. Suitability of evaluation with learning objectives $87.10 \%$.
\end{abstract}

Keywords: Interactive Learning Media, Problem Based Learning, Basic Physics, R\&D, Learning Models.

\section{PENDAHULUAN}

Dewasa ini pendidikan menjadi salah satu bidang yang selalu diperhatikan oleh pemerintah maupun masyarakat. Kesadaran masyarakat akan pentingnya pendidikan menimbulkan sikap selektif masyarakat untuk memilih tempat pendidikan yang lebih berkualitas. Kualitas pendidikan sendiri bisa berupa dari tenaga pendidik maupun sarana prasarana sekolah. Tenaga pendidik yang baik dan mampu melaksanakan proses pembelajaran yang efektif sehingga penyerapan materi ajar yang disampaikan menjadi pertimbangan penting bagi masyarakat. Perhatian pemerintah terhadapat pendidikan juga sangat tinggi, hal ini terlihat dari terus berkembangnya kurikulum pendidikan maupun perkembangan metode pembelajran yang selalu di ajukan oleh tim ahli dalam pendidikan.

Tingginya tuntutan terhadap dunia pendidikan menjadi tugas penting bagi seorang pengajar untuk bisa menyajikan proses pembelajaran yang menarik, efektif dan efisien. Seorang pengajar bukan hanya mampu menerapkan metode dan model pembelajaran terbaru di dalam kelas, tapi juga dituntut untuk bisa melakukan inovasi dan perancangan pembelajaran di dalam kelas. Perancangan proses pembelajaran di dalam kelas ini bisa meliputi media pembelajaran.

Universitas potensi utama adalah salah satu dari universitas yang menggunakan kurikulum KKNI. Kurikulum KKNI ini menuntut perwujudan mutu dan jati diri bangsa mengenai pendidikan ${ }^{[5]}$, hal ini sesuai dengan Perpres no 08 tahun 2012. Kurikulum KKNI ini dapat kita lihat menuntut pada perkembangan teknologi yang dapat digunakan dalam pendidikan. Berdasarkan UU no 14 Thn 2005 mengenai kewajiban guru dan dosen. Seorang dosen dituntut untuk dapat melakukan perencanaan dan proses pembelajaran dan mengevaluasi pembelajaran. Bukanhanya melakukan pembelajaran, tetapi merancang pembelajaran juga merupakan kewajiban dari seorang dosen [8].

Proses pembelajaran yang digunakan selama di universitas potensi utama ini sudah mengacu pada teknologi, mulai dengan menggunakan LCD sebagai alat bantu pembelajaran, maupun membuat media pembelajaran yang berbasis teknologi. Matakuliah fisika dasar merupakan salahsatu matakuliah sciens yang sangan menarik jika menggunakan pendekatan saintifik. Pendekatan saintifik ini mengusung beberapa model pembelajaran salahsatunya adalah PBL (Project Based Learning). Model pembelajaran PBL juga sesuai dengan 
Permendikbud Nomor 81 A Tahun 2013 Lampiran IV mengenai proses pembelajaran yaitu (1) Mengamati, (2) Menanya, (3) Mengumpulkan informasi, (4) Mengasosiasi, (5) Mengkomunikasikan [6].

Pentingnya kesesuaian antara media pembelajaran dan model pembelajaran yang digunakan bertujuan untuk mencapai tujuan dari pembelajaran itu sendiri ${ }^{[3]}$, hal ini sesuai dengan pernyataan Majid (2009). Kesesuaian antara media pembelajaran berbasis model pembelajaran ini sebelumnya pernah dilakukan penelitian oleh Astawan, K.W (2013) dengan judul Pengembangan Modul Berbasis Model Pembelajaran Kooperatif Tipe Group Investigation Pada Mata Pelajaran Server Jaringan Di Smk Ti Bali Global Singaraja. [1]. Hasil dari penelitian yang dilakukan adalah adanya peningkatan hasil belajar pada kelas yang diterapkan modul pembelajaran berbasis model pembelajaran kooperatif tipe group investigation, yaitu dengan nilai rata-rata posttest 8,68 dengan katagori sangat baik. Benny Satria Wahyudi (2014) dengan judul Pengembangan Bahan Ajar Berbasis Model Problem Based Learning Pada Pokok Bahasan Pencemaran Lingkungan Untuk Meningkatkan Hasil Belajar Siswa Kelas X Sma Negeri Grujugan Bondowoso ${ }^{[9]}$. Hasil dari penelitian tersebut adalah terjadinya peningkatan hasil belajar siswa dari pretest dan posttest yang dilakukan sebesar 32,30\%

Berdasarkan sistem kurikulum yang digunakan di universitas potensi utama dan tuntutan seorang dosen berdasarkan UU no 14 thn 2005, maka peneliti merasa penting untuk merancang media pembelajaran yang berbasis dengan project based learning. Sesuai dengan peneliti sebelumnya yang sudah membuktikan adanya hubungan yang signifikan antara kesesuaian media pembelajaran dan model pembelajaran. Penelitian ini dilakukan pada matakuliah fisika dasar khususnya materi HK. Newton yang tepatnya pada mahasiswa semester I.

\section{METODE PENELITIAN}

Penelitian ini dilakukan di universitas potensi utama beralamat Jl. KL Yos Sudarso, Tj. Mulia, Kec Medan Deli Kota Medan, Sumatera Utara 59391.Penelitian perancangan media pembelajaran ini menggunakan metodologi R\&D (Research and Development) yaitu metodologi yang menghasilkan produk tertentu[4]. Produk yang dihasilkan pada penelitian ini adalah media pembelajaran berbasis model pembelajaran PBL. Langkah-langkah penelitian R\&D dapat dilihat pada gambar 1.

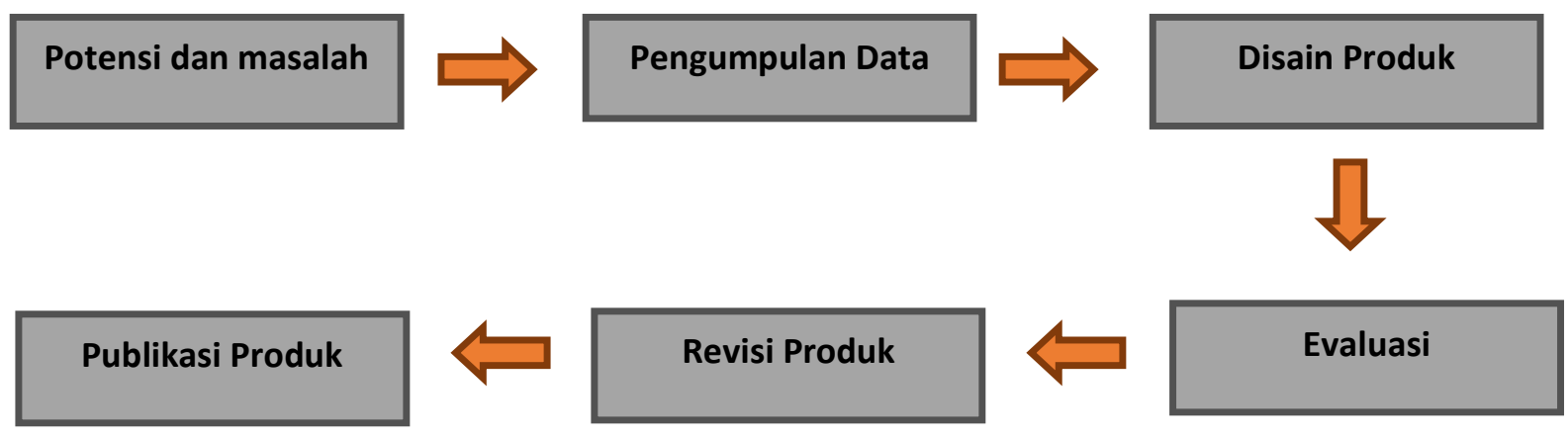

Gambar 1. Langkah-langkah penggunaan Metode Research and Development (R\&D)

Rancangan media pembelajaran ini disesuaikan dengan Rencana Pembelajaran Semester (RPS) yang mengacu pada sistem KKNI pada Universitas Potensi Utama, yaitu :

1. Ilmu Pengetahuan (Science).

2. Pengetahuan (Knowledge).

3. Pemahaman (Know-How)

4. Keterampilan (Skill)

5. Afeksi (Affection)

6. Kompetensi (Competency)

\section{HASIL DAN PEMBAHASAN}

Pada penelitian peneliti menggunakan beberapa orang tim ahli dalam hal bidang pendidikan fisika dan bidang tekhnologi. Tim ahli pada bidang pendidikan fisika peneliti menggunakan dosen-dosen fisika dan guru-guru fisika. Tim ahli untuk bidang tekhnologi peneliti menggunakan praktisi bidang IT.

Model pembelajaran PBL (Problem Based Learning) terdiri dari enam fase yaitu :

1. Pengajuan permasalahan. 


\section{JURNAL MEDIA INFORMATIKA BUDIDARMA}

Volume 4, Nomor 1, Januari 2020, Page 245-249

ISSN 2614-5278 (media cetak), ISSN 2548-8368 (media online)

Available Online at https://ejurnal.stmik-budidarma.ac.id/index.php/mib

DOI $10.30865 /$ mib.v4i1.1974

2. Apa yang diketahui diketahui dari permasalahan?

3. Apa yang tidak diketahui dari permasalahan?

4. Alternatif Pemecahan.

5. Laporan dan Presentasi Hasil.

6. Pengembangan Materi.

Hasil tampilan dari media pembelajaran berbasis model pembelajaran PBL dapat dilihat pada gambar 2 :

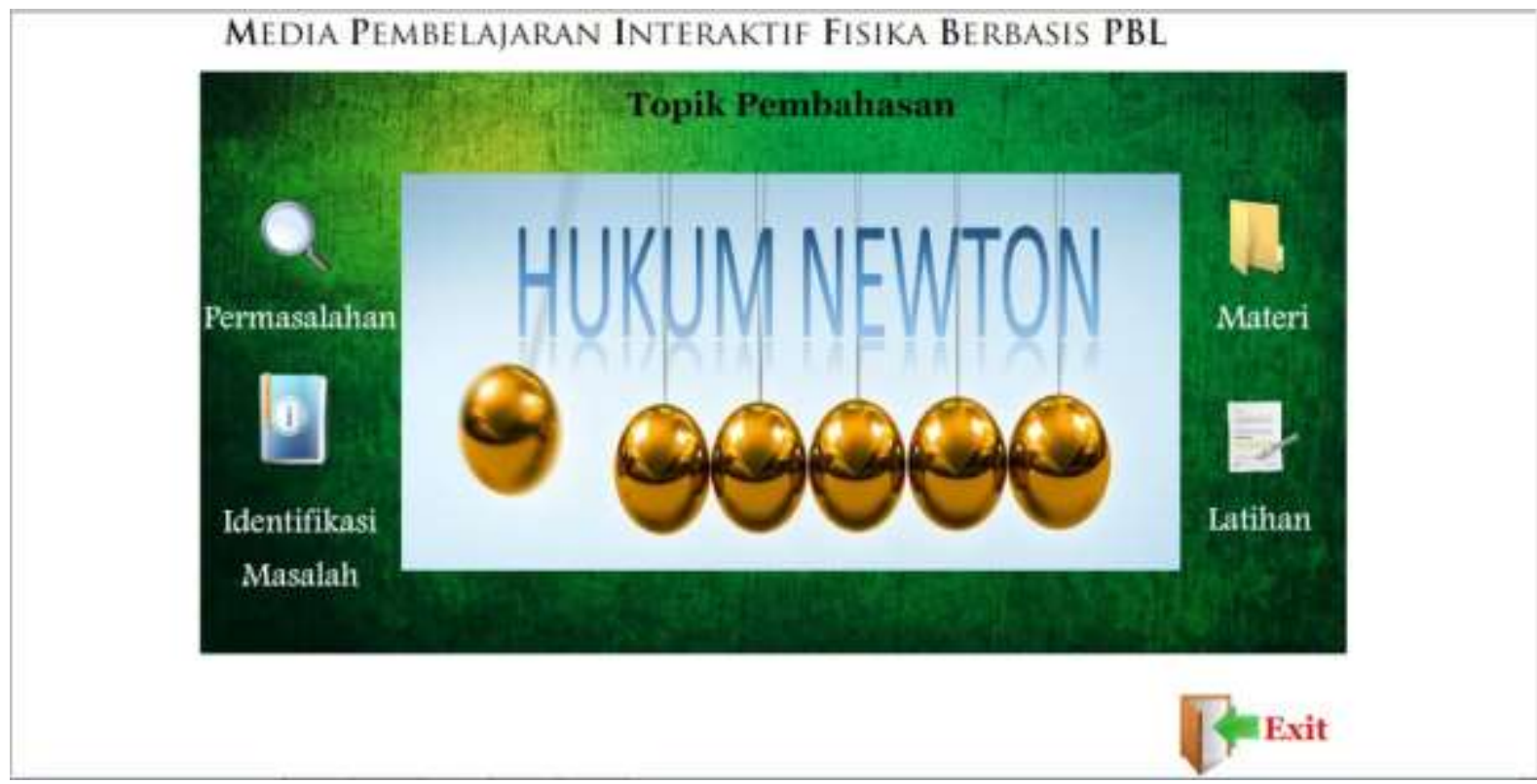

Gambar 2. Tampilan Utama Media Pembelajaran Berbasis Model Pembelajaran PBL

Tampilan fase pertama pada model pembelajaran PBL dapat dilihat pada gambar 2.

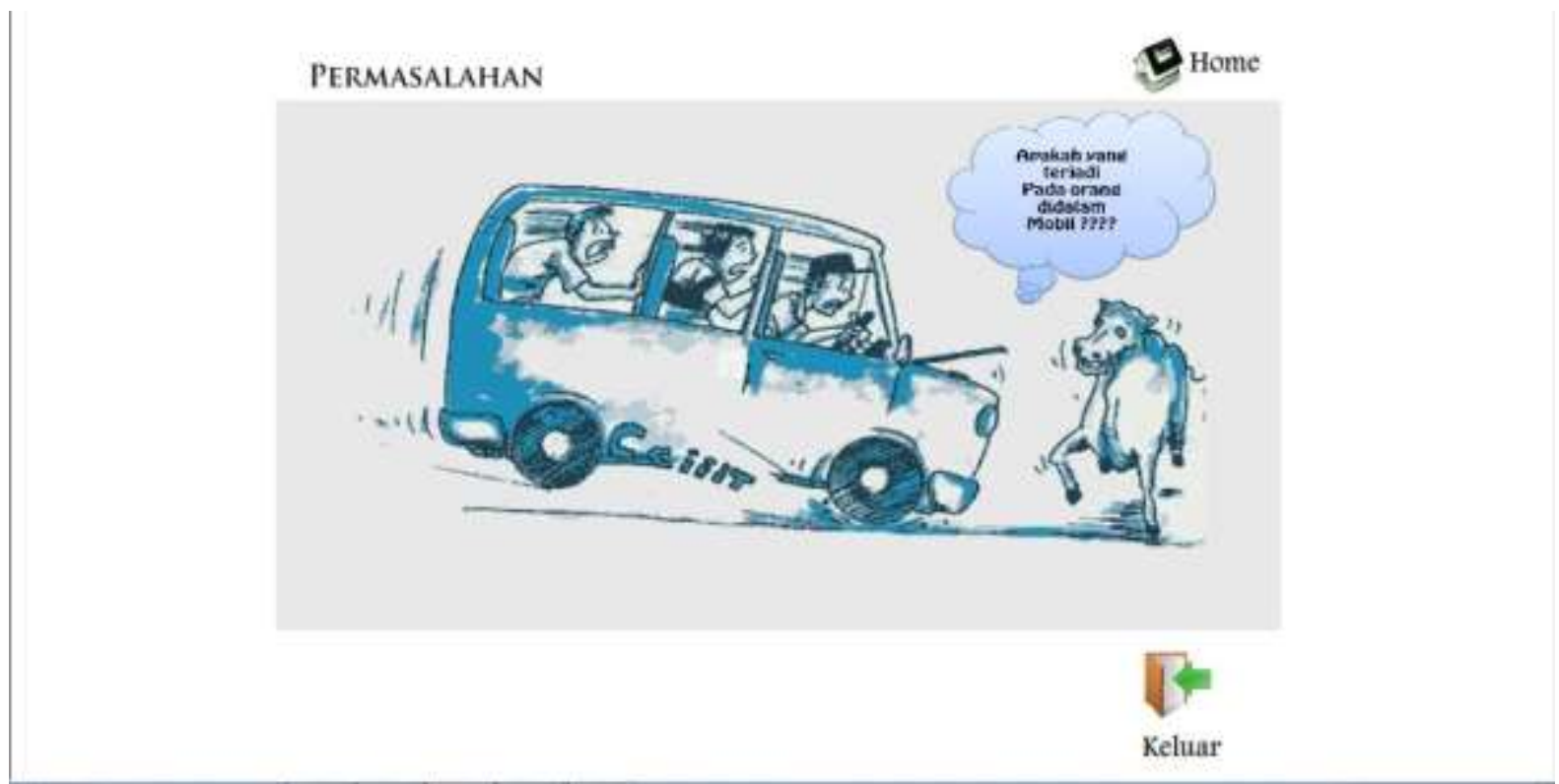

Gambar 3.Tampilah Fasse Pertama Pada Media Pembelajaran Berbasis Model Pembelajaran PBL

Tampilan pada fase ke tiga yaitu mengetahui masalah, pada Media Pembelajaran Berbasis Model Pembelajaran PBL dapat dilihat pada gambar 4. 


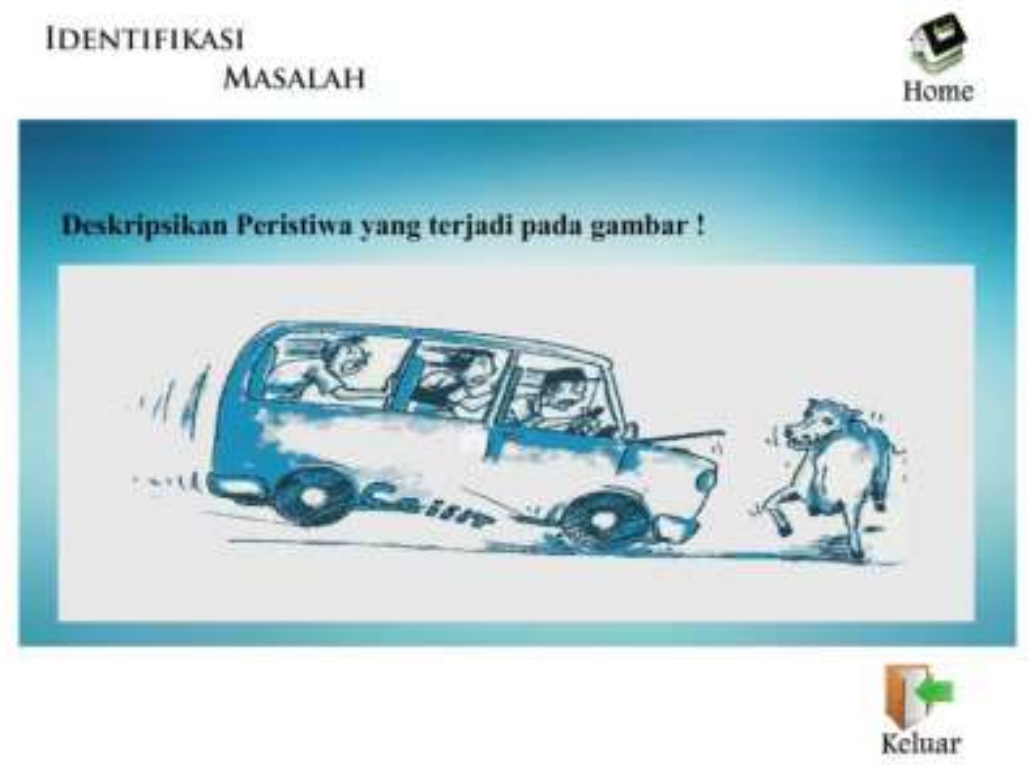

Gambar 4. Tampilan pada fase ke tiga pada Media Pembelajaran Berbasis Model Pembelajaran PBL gambar 5 .

Tampilan untuk materi pada media pembelajaran berbasis model pembelajaran PBL dapat dilihat pada

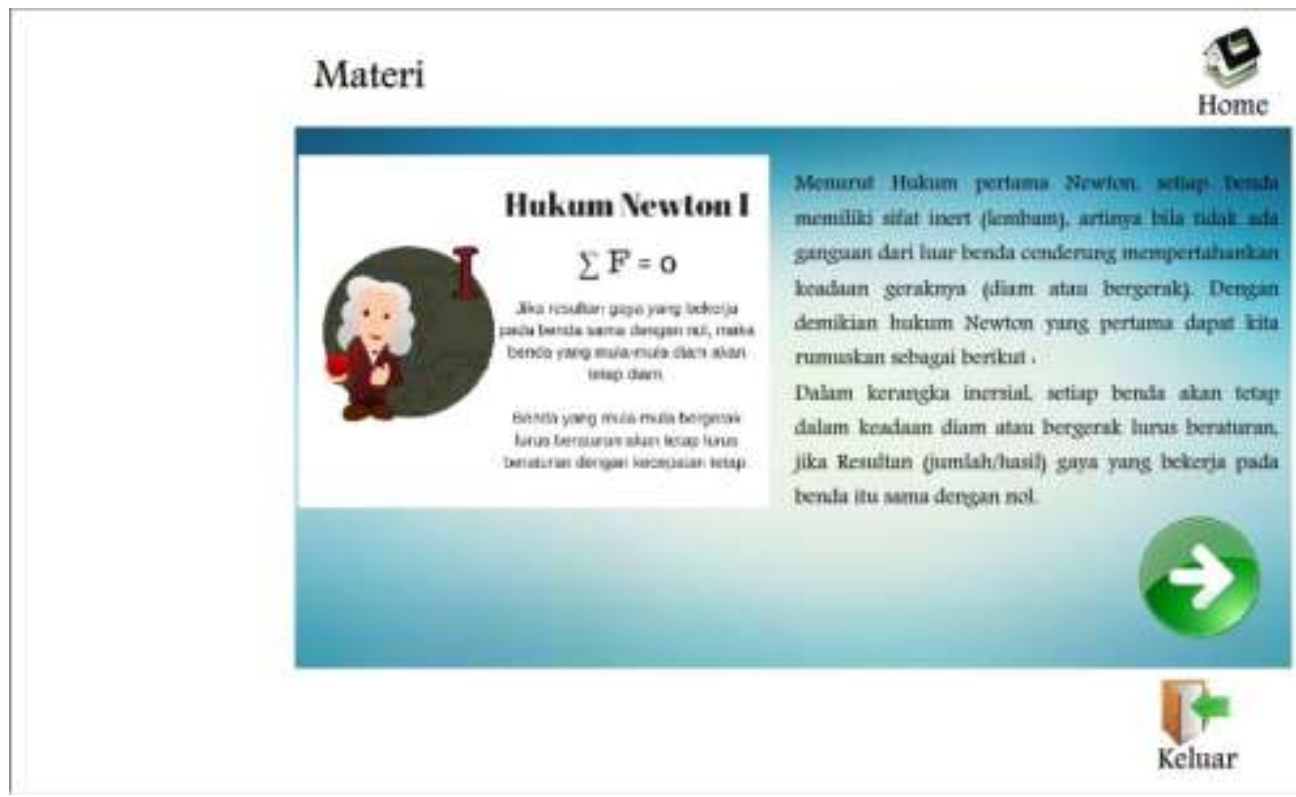

Gambar 5. Tampilan untuk materi pada media pembelajaran berbasis model pembelajaran PBL

Media pembelajaran yang dirancang kemudian dinilai oleh tim ahli mulai dari kesesuaian dengan materi yang akan diajarkan hingga kesesuaian dengan tujuan dari pembelajaran itu sendiri. Hasil dari penilaian tim ahli untuk kesesuaian dengan materi fisika dapat dilihat pada tabel 1 :

Tabel 1. Hasil Penilaian Tim Ahli untuk Kesesuaian Materi

\begin{tabular}{lll}
\hline No & Aspek & Persentase \\
\hline 1 & Kelayakan Isi / kedalaman materi tingkat universitas & $82,85 \%$ \\
2 & Kontekstual & $81,20 \%$ \\
3 & Kelayakan Penyajian & $80,15 \%$ \\
4 & Kesesuaian dengan model PBL & $86,25 \%$ \\
5 & Kesesuaian evaluasi dengan tujuan pembelajaran & $87,10 \%$ \\
\hline
\end{tabular}


Berdasarkan tabel di atas dapat kita lihat bahwa kelayakan isi/ kedalaman materi tingkat universitas dengan nilai persentase $82,85 \%$. Kontekstual persentase $81,20 \%$. Kelayakan Penyajian 80,15\%. Kesesuaian dengan model. PBL $86,25 \%$. Kesesuaian evaluasi dengan tujuan pembelajaran $87,10 \%$..

\section{KESIMPULAN}

Hasil dari penelitian ini dapat disimpulkan bahwa :

1. Media pembelajaran berbasis PBL ini cukup layak dan sesuai dengan materi fisika khususnya HK. Newton. Penilaian kelayakan materi oleh tim ahli adalah kelayakan isi/ kedalaman materi tingkat universitas dengan nilai persentase $82,85 \%$. Kontekstual persentase $81,20 \%$. Kelayakan Penyajian $80,15 \%$. Kesesuaian dengan model. PBL 86,25\%. Kesesuaian evaluasi dengan tujuan pembelajaran 87,10\%.

2. Perancangan media Pembelajaran dapat berjalan dengan baik saat digunakan dalam proses pembelajaran matakuliah fisika dasar.

\section{UCAPAN TERIMAKASIH}

Terima kasih disampaikan kepada pihak-pihak yang telah mendukung terlaksananya penelitian ini.

\section{REFERENCES}

[1] Astawan. 2013. Pengembangan Modul Berbasis Model Pembelajaran Kooperatif Tipe Group Investigation Pada Mata Pelajaran Server Jaringan Di Smk Ti Bali Global Sarjana. E-Journal Program Pascasarjana Universitas Pendidikan Ganesha. Vol 3-2013.

[2] Budiyasa, I.M. 2013. Pengembangan bahan ajarassessment alternatif online mata pelajaran IPA tingkat SMP kelas Delapan dengan model Dick and Carey. E-Journal Program Pascasarjana Universitas Pendidikan Ganesha. Vol 3-2013

[3] Majid, A. 2009. Mengembangkan Standar Kompetensi Guru. Bandung: Remaja Rosdakarya.

[4] Sugiyono. (2011). Metode Penelitian Kuantitatif Kualitatif dan R\&D. Bandung. Alfabeta

[5] Peraturan Presiden Republik Indonesia no 8 Tahun 2012 tentang Kerangka Kualifikasi Nasional Indonesia

[6] Permendikbud Nomor 81 A Tahun 2013 tentang Implimentasi Kurikulum

[7] Trianto. 2007. Model-model Pembelajaran Inovatif Berorientasi Konstruktivistik. Jakarta: Prestasi Pustaka.

[8] Undang-undang No 14 Tahun 2005 tentang Guru dan Dosen

[9] Wahyudi,BS. Pengembangan bahan ajar berbasis model Problem based Learning Pada Pokok Bahasan Pencemaran Lingkungan Untuk meningkatkan hasil belajar siswa Kelas x sma negeri grujugan Bondowoso. E-Journal Pancaran Pendidikan FKIP Universitas Jember. Vol 3 No 3-2014. 